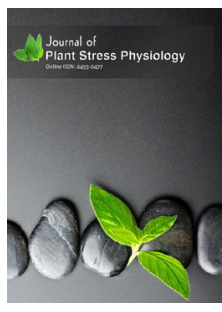

ISSN: $2455^{-0} 0477$

Received: February 18, 2019

Accepted: March 27, 2019

Published: April 01, 2019

*Corresponding Author:

A. E. Sharief

Email: shariefali42@gmail.com

\section{Influence of antioxidants and salinity stress on seedling parameters of some rice cultivars}

\author{
A. A. Kandil', A. E. Sharief'*, Fatma M. Abd EL-Fatah² \\ 'Department of Agronomy, Faculty of Agriculture, Mansoura University, Egypt, ${ }^{2}$ Central Administration for Seed \\ certification (CASC), Ministry of Agriculture, Egypt
}

\begin{abstract}
An investigation was conducted to study the response of antioxidants seed priming on rice cultivars and their effect on germination under salinity levels. The result indicated that the highest in shoot height $(\mathrm{cm})$, root height $(\mathrm{cm})$, seedling vigor index, and other related parameters, relative dry weight\% were produced from Sakha 106 cultivar. The lowest seedling height reduction\% was produced from Sakha 106 cultivar. An enhancement in salt concentration resulted a reduction in all studied parameters except seedling height reduction\%. The results indicated the highest shoot height $(\mathrm{cm})$, root height $(\mathrm{cm})$, seedling vigor index, shoot fresh and dry weight $(\mathrm{mg})$, root fresh and dry weight $(\mathrm{mg})$, relative dry weight\% and seedling height reduction\% from which soaking, as pretreatment, in Humic acid at 500ppm. The interactions between cultivars, salinity concentration and antioxidants were insignificant on some traits. It could be concluded that to improve seedling parameters of rice cultivars under salinity stress; it could be recommended that soaking Sakha 106 cultivar seed in Humic acid at $500 \mathrm{ppm}$ for $24 \mathrm{~h}$. It can be used in breeding program to boost production in Egyptian territory.
\end{abstract}

KEY WORDS: Rice cultivars, antioxidants, salinity levels, seedling characters

\section{INTRODUCTION}

Rice (Oryza sativa L) is one among the important staple foods in many countries. Soil or water salinity is a major hindering factor for the rice cultivation across the world [1].Salinity creates a negative impact and there by a stress on most of the plants [2]. For increasing rice productivity, in Egypt, due to increases in Egyptian population, cultivation area of rice should be increased by using new salt reclaimed soils. Genotypes of rice showed different susceptibilities towards salinity stress $[3,4,5]$. Treatments of seeds of Giza 177 and Sakha 103 cultivars with salicylic or ascorbic acid induced one Esterase3 isoenzymes. Presowing rice seed of Sakha 104 cultivar with Ascorbic produced the highest seedling dry weight and the lowest mean germination time as well as time $50 \%$ germinated seed compared with other two cultivars under salinity condition [6].There was a significant difference between native (Arvand and Sholeh) and breeded (Chamran and Dez) of rice varieties in vigour index, stem length, stem dry matter and seedling dry matter at all salinity levels [7]. The antioxidant enzyme activities were showed remarkable variations under salinity stress in plants $[8,9]$.

During rice seedling establishment, mostly in all stages salinity is a major problem inhibiting growth and productivity in rice [10].
A decrease in rice productivity was reported by various authors under salinity stress [11-15].

The aims of the present investigation were to identify the individual and combined effects of antioxidants and salinity in rice, during germination stage.

\section{MATERIALS AND METHODS}

\section{Treatments and Experimental Design}

A laboratory experiment conducted in the Giza Central Seed Testing Laboratory of Central Administration for Seed Certification (CASC), Ministry of Agriculture Egypt during April and May 2017. Theaims of this investigation aimed to study the response to antioxidants seed prim of some rice cultivars to seedling parameters under salinity stress. Factorial experiment assigned to Randomized Complete Block Design in four replications used. The five rice cultivars, Giza 178, Egyptian Hybrid 1, Sakha 101, Sakha 104 and Sakha 106 includes the first factor used. The second factor consists of the four salinity levels 0, 100, 200 and $300 \mathrm{mM}$. The four types of antioxidants, Salicylic acid 100 ppm, Ascorbic acid 100 ppm, Follic acid

Copyright: $\odot$ The authors. This article is open access and licensed under the terms of the Creative Commons Attribution License (http://creativecommons.org/licenses/by/4.0/) which permits unrestricted, use, distribution and reproduction in any medium, or format for any purpose, even commercially provided the work is properly cited. Attribution - You must give appropriate credit, provide a link to the license, and indicate if changes were made. 
$15 \mathrm{mM}$ and Humic acid 500 ppm. Selected cultivars obtained from Rice Research Institute at Sakha, ARC and stored under normal conditions in paper bags. Seed of each rice cultivar was primed in the four antioxidants at above concentrations of 24 hours except the control. The germination experiment was conducted according to ISTA [16].

\section{Studied Measurements}

The following of eight seedling characters were measured, namely the length of shoot and radical, the fresh weight of shoot and radical, the dry weight of shoot and radical, seedling vigor index, percentages of seedling height reduction and relative dry weight.

The seedling vigor index was intended as the formula described previously [17].

Percentage of seedling height reduction (SHR \%) and Percentage of (RDW \%) was measured by using the following formula described earlier [18].

\section{Experimental Analysis}

The data collected from the experiment was analyzed technique of variance using the MSTAT-C statistical package programmed as described by system of Gomez and Gomez [19]. Treatment means was compared at 5 and $1 \%$ level of probability using the least significant differences test (LSD) according to Snedecor and Cochran [20].

\section{RESULTS AND DISCUSSION}

\section{Cultivar Performance}

Average of the shoot and root length $(\mathrm{cm})$, the seedling vigor index, and other morphological parameters in rice cultivars are presented in Tables (land 2). It is clear that there were significant differences due to cultivars in shoot and root length $(\mathrm{cm})$, and seedling vigor index. The results showed variations and Sakha 106 cultivar recorded highest shoot height, root height and seedling vigor index. While, the lowest shoot height, root height and seedling vigor index were obtained from Giza 178. The results showed that there were significant differences due to cultivars in shoot and root fresh weight, shoot and root dry weigh, shoot and root fresh weight, shoot and root dry weight. The result clearly indicated that Sakha 106 cultivar recorded highest shoot and root fresh weight, shoot and root dry weight. While, the lowest was obtained from Sakha 101 cultivar in shoot fresh weight but Egyptian hybrid 1 recorded the lowest in root fresh weight, shoot and root dry weight. Regarding to the percentages of seedling height reduction and relative dry weight as affected by rice cultivars are obtainable in Table (3). The results showed that there were significant differences due to cultivars in seedling height reduction (\%) and relative dry weight. The result clearly indicated that, Giza 178 cultivar recorded the highest Seedling height reduction (\%), While, the lowest was obtained from Sakha 106 cultivar, On the other hand,
The results clearly indicated that, Sakha 106 cultivar recorded highest relative dry weight (\%), While, the lowest percentages was recorded by Giza 178 cultivar. Our results are in accordance with the previous studies $[5,18,20,21,22]$.

\section{Salinity Stress Effects}

Averages of shoot and root length $(\mathrm{cm})$ and seedling vigor index, shoot and root fresh weight $(\mathrm{mg})$, shoot and root dry weight $(\mathrm{mg})$ as affected by salinity stress are obtainable in Tables (4 and 5). The results showed that a significant difference due

Table 1: Means of shoot and root length (cm), and seedling vigor index, as affected by rice genotypes

\begin{tabular}{|c|c|c|c|}
\hline Treatments Characters & $\begin{array}{l}\text { Shoot length } \\
(\mathrm{cm})\end{array}$ & $\begin{array}{l}\text { Root length } \\
\text { (cm) }\end{array}$ & $\begin{array}{l}\text { Seedling vigor } \\
\text { index }\end{array}$ \\
\hline \multicolumn{4}{|l|}{ Cultivars } \\
\hline Giza 178 & 5.35 & 4.43 & 753.9 \\
\hline Egyptian Hybrid 1 & 8.94 & 6.55 & 1196.7 \\
\hline Sakha 101 & 6.42 & 5.13 & 861.0 \\
\hline Sakha 104 & 8.75 & 6.59 & 1169.6 \\
\hline Sakha 106 & 11.31 & 7.25 & 1619.6 \\
\hline LSD at $5 \%$ & 0.08 & 0.10 & 15.2 \\
\hline
\end{tabular}

Table 2: Means of the fresh weight of shoot and radical and the dry weight of shoot and radical as affected by studied rice genotypes

\begin{tabular}{|c|c|c|c|c|}
\hline Treatments $\quad$ Characters & $\begin{array}{l}\text { Shoot fresh } \\
\text { weight mg }\end{array}$ & $\begin{array}{l}\text { Root fresh } \\
\text { weight mg }\end{array}$ & $\begin{array}{l}\text { Shoot dry } \\
\text { weight mg }\end{array}$ & $\begin{array}{l}\text { Root dry } \\
\text { weight mg }\end{array}$ \\
\hline \multicolumn{5}{|l|}{ Cultivars } \\
\hline Giza 178 & 22.34 & 7.09 & 3.22 & 2.36 \\
\hline Egyptian Hybrid 1 & 21.07 & 4.05 & 3.21 & 1.77 \\
\hline Sakha 101 & 18.84 & 4.92 & 3.22 & 1.93 \\
\hline Sakha 104 & 24.00 & 5.42 & 3.74 & 1.94 \\
\hline Sakha 106 & 28.54 & 11.48 & 3.79 & 2.64 \\
\hline LSD at $5 \%$ & 3.73 & 0.13 & 0.11 & 0.06 \\
\hline
\end{tabular}

Table 3: Percentages of the seedling height reduction and the relative dry weight as affected by studied rice genotypes

\begin{tabular}{lcc}
\hline Treatments & $\begin{array}{c}\text { Seedling height } \\
\text { reduction \% }\end{array}$ & $\begin{array}{c}\text { Relative dry } \\
\text { weight \% }\end{array}$ \\
\hline Cultivars & & 64.93 \\
Giza 178 & 53.77 & 73.92 \\
Egyptian Hybrid 1 & 33.44 & 71.95 \\
Sakha 101 & 41.63 & 67.77 \\
Sakha 104 & 46.68 & 88.78 \\
Sakha 106 & 33.29 & 1.62 \\
LSD at 5\% & 0.60 &
\end{tabular}

Table 4: Means of the length of shoot and root and the seedling vigor index as exaggerated by salinity concentrations

\begin{tabular}{|c|c|c|c|}
\hline $\begin{array}{ll} & \text { Characters } \\
\text { Treatments }\end{array}$ & $\begin{array}{l}\text { Shoot length } \\
(\mathrm{cm})\end{array}$ & $\begin{array}{l}\text { Root length } \\
\text { (cm) }\end{array}$ & $\begin{array}{l}\text { Seedling vigor } \\
\text { index }\end{array}$ \\
\hline \multicolumn{4}{|l|}{ Salinity stress } \\
\hline $0 \mathrm{mM}$ & 9.87 & 7.57 & 1515.4 \\
\hline $100 \mathrm{mM}$ & 8.70 & 6.30 & 1244.9 \\
\hline $200 \mathrm{mM}$ & 7.86 & 5.50 & 992.9 \\
\hline $300 \mathrm{mM}$ & 6.19 & 4.59 & 727.6 \\
\hline LSD at $5 \%$ & 0.07 & 0.90 & 13.6 \\
\hline
\end{tabular}


to salinity levels on shoot and root length $(\mathrm{cm})$ and shoot and root fresh weight, shoot and root dry weight seedling vigor index. Increasing salinity concentrations significantly reduced shoot and root length $(\mathrm{cm})$ and seedling vigor index, shoot and root fresh weight, shoot and root dry weight. The tallest shoot and root length $(9.78$ and $7.57 \mathrm{~cm})$, respectively and highest seedling vigor index (1515.4) The highest shoot and root fresh weight (27.31 and $8.43 \mathrm{mg}$.), shoot and root dry weight (4.69 and $2.98 \mathrm{mg}$ ), respectively were obtained from the control treatment The shortest shoot and root length $(\mathrm{cm})$ and lowest seedling vigor index, the lowest shoot and root fresh weight, the lowest shoot and root dry weight were recorded from the highest salinity level of $300 \mathrm{mM}$ of Nacl. Multiple levels of lethality has been reported under salt stress in various plants by different authors [23, 24, 25], our results are in accordance with those reports.

Concern to percentages of seedling height reduction, as affected by salinity levels exist in Table (6). The results showed that a significant difference due to salinity levels on seedling height reduction (\%). Increasing salinity levels significantly increased seedling height reduction (\%). In addition; relative dry weight (\%) significantly differed as shown in Table (6). The highest percentages of relative dry weight were obtained from the control treatment. While, the lowest relative dry weight (\%) recorded from the highest salinity level of $300 \mathrm{mM}$. Similar conclusions were obtained from results of previous reports $[5,12,18,26]$.

\section{Antioxidants Effects}

Mean values ofmorphological parameters under influence of antioxidants are illustrated in Tables (7 and 8). It is clear that there were significant differences in shoot and root length $(\mathrm{cm})$ and seedling vigor index, shoot and root fresh weight (mg.) shoot and root dry weight (mg) due to studied antioxidants. The tallest shoot $(8.65 \mathrm{~cm})$, root length $(6.25 \mathrm{~cm})$ and highest seedling vigor index (1227.7), shoot (23.73) and root fresh weight $(6.99 \mathrm{mg})$ shoot $(3.57 \mathrm{mg})$ and root dry weight $(2.23 \mathrm{mg})$

Table 5: Means of the fresh weight of shoot and root (mg), the dry shoot and root weight (mg) as affect by salinity concentrations

\begin{tabular}{lcccc}
\hline Characters & $\begin{array}{c}\text { Shoot fresh } \\
\text { weight mg }\end{array}$ & $\begin{array}{c}\text { Root fresh } \\
\text { weight mg }\end{array}$ & $\begin{array}{c}\text { Shoot dry } \\
\text { weight mg }\end{array}$ & $\begin{array}{c}\text { Root dry } \\
\text { weight mg }\end{array}$ \\
\hline Salinty stress & & & & \\
$0 \mathrm{mM}$ & 27.31 & 8.43 & 4.69 & 2.98 \\
$100 \mathrm{mM}$ & 23.19 & 6.83 & 3.59 & 2.17 \\
$200 \mathrm{mM}$ & 23.12 & 5.95 & 3.02 & 1.80 \\
$300 \mathrm{mM}$ & 18.20 & 5.17 & 2.45 & 1.56 \\
LSD at 5\% & 3.43 & 0.12 & 0.09 & 0.05 \\
\hline
\end{tabular}

Table 6: Percentages of the seedling height reduction and relative dry weight as affect by salinity concentrations

\begin{tabular}{lcc}
\hline Treatments & $\begin{array}{c}\text { Seedling height } \\
\text { reduction \% }\end{array}$ & $\begin{array}{c}\text { Relative dry } \\
\text { weight \% }\end{array}$ \\
\hline Salinity stress & & \\
$0 \mathrm{mM}$ & 0.00 & 100.00 \\
$100 \mathrm{mM}$ & 28.81 & 75.64 \\
$200 \mathrm{mM}$ & 44.97 & 63.45 \\
$300 \mathrm{mM}$ & 83.66 & 54.78 \\
LSD at 5\% & 0.54 & 1.45 \\
\hline
\end{tabular}

were produced from soaking seed in Humic acid at 500 ppm. Our reports are in accordance with previous reports by various researchers [8, 9, 27, 28, 29].

Percentages of relative dry weight and seedling height reduction $(\%)$ as prejudiced by antioxidants are accessible in Table (9). The results showed that there were significant differences in relative dry weight (\%) and seedling height reduction (\%) by antioxidants. The highest relative dry weight $(79.8 \%)$ and seedling height reduction $(49.19 \%$ ) was obtained from seed soaking in Humic acid at 500 ppm compared with the control treatment and other treatments. While, the lowest relative dry weight (67.1\%) was obtained the control treatment and lowest seedling height reduction $(35.3 \%)$ was obtained from soaking in Salicylic acid at $100 \mathrm{ppm}$ compared with other treatments. These results are in agreement with earlier studies [30, 31].

\section{Interaction between rice cultivars and salinity levels effect}

Means of shoot and root length $(\mathrm{cm})$ shoot and root dry weight as affected by the interaction between cultivars and NaCL salinity concentration are illustrated in Figures. 1,2, 3 and 4. The results showed that the length of shoot and root $(\mathrm{cm})$, the

Table 7: Means of shoot and root length and seedling vigor index as affected by antioxidants

\begin{tabular}{lccc} 
Treatments & $\begin{array}{c}\text { Shoot } \\
\text { length }(\mathrm{cm})\end{array}$ & $\begin{array}{c}\text { Root } \\
\text { length }(\mathrm{cm})\end{array}$ & $\begin{array}{c}\text { Seedling } \\
\text { vigor index }\end{array}$ \\
\hline Antioxidants & & & \\
Control & 7.36 & 5.19 & 1169.5 \\
Humic acid at $500 \mathrm{ppm}$ & 8.65 & 6.21 & 1227.8 \\
Ascorbic acid at $100 \mathrm{ppm}$ & 8.10 & 5.81 & 1116.5 \\
Folic acid at 15 mM ppm & 7.75 & 5.91 & 1070.1 \\
Salicylic acid at 100 ppm & 7.91 & 5.84 & 1017.1 \\
LSD at 5\% & 0.08 & 0.10 & 15.2 \\
\hline
\end{tabular}

Table 8: Averages of the fresh weight of shoot and radical, the dry weight of shoot and radical as affected antioxidants

\begin{tabular}{lcccc}
\hline Treatments & Characters & $\begin{array}{c}\text { Shoot fresh Root fresh } \\
\text { weight } \mathrm{mg}\end{array}$ & $\begin{array}{c}\text { Shoot dry } \\
\text { weight } \mathrm{mg} \\
\text { weight mg }\end{array}$ & $\begin{array}{c}\text { Root dry } \\
\text { weight mg }\end{array}$ \\
\hline Antioxidants & & & & \\
Control & 22.41 & 6.00 & 2.62 & 1.26 \\
Humic acid at $500 \mathrm{ppm}$ & 23.73 & 6.99 & 3.57 & 2.23 \\
Ascorbic acid at $100 \mathrm{ppm}$ & 23.65 & 6.51 & 3.65 & 2.18 \\
Folic acid at $15 \mathrm{mM} \mathrm{ppm}$ & 20.21 & 6.48 & 3.52 & 2.07 \\
Salicylic acid at $100 \mathrm{ppm}$ & 23.77 & 5.99 & 2.83 & 1.90 \\
LSD at 5\% & N.S. & 0.13 & 0.11 & 0.06 \\
\hline
\end{tabular}

Table 9: Percentages of the seedling height reduction and percentage of relative dry weight as affected by antioxidants

\begin{tabular}{lcc}
\hline Treatments & $\begin{array}{c}\text { Relative dry } \\
\text { weight (\%) }\end{array}$ & $\begin{array}{c}\text { Seedling height } \\
\text { reduction (\%) }\end{array}$ \\
\hline Antioxidants & 67.1 & 38.6 \\
Control & 79.8 & 49.2 \\
Humic acid at $500 \mathrm{ppm}$ & 77.2 & 40.8 \\
Ascorbic acid at $100 \mathrm{ppm}$ & 74.3 & 45.8 \\
Folic acid at $15 \mathrm{mM} \mathrm{ppm}$ & 68.7 & 35.3 \\
Salicylic acid at $100 \mathrm{ppm}$ & 1.6 & 0.6 \\
LSD at 5\% &
\end{tabular}


dry weight of shoot and radical significantly affected by the interaction between cultivars and NaCL salinity concentration. It could indicated that the tallest shoot $(13.2 \mathrm{Cm})$, shoot $(5.71 \mathrm{mg})$ and root dry weight $(3.98 \mathrm{mg})$ from Sakha 106 cultivar at the control treatment and tallest root $(9.5 \mathrm{Cm})$ was recorded from Sakha 104 cultivar at the control treatment. Similar conclusions were reported by many researchers in the past $[9,10,11,13,14,18]$.

\section{The interaction between rice cultivars and antioxidants effect}

With respect to the interaction effect between cultivars and antioxidants on shoot length, root fresh weight, root dry weights and seedling vigor index are demonstrated in Figures. 5, 6, 7 and 8. The results indicate that the interface between antioxidants and rice cultivars significantly affected the length of shoot, fresh and dry weight of root, and the seedling vigor index. The tallest shoot $(12.25 \mathrm{Cm})$, highest root fresh weight $(12.64 \mathrm{mg})$, root dry weight $(3.31 \mathrm{mg}$ ) and seedling vigor index (1755.6) are produced from Sakha 106 cultivar when seed soaked in Humic acid at $500 \mathrm{ppm}$. Comparable conclusions were obtained in various studies $[5,7,11]$.

\section{Interaction among antioxidants and salinity levels effect}

Regarding to the interface effect connecting salinity concentration and antioxidants on root length, root fresh weight (mg), root dry weight (gm) and seedling vigour index are illustrated in Figures. 9, 10, 11 and 12. The results showed that the interaction effect between salinity concentration and antioxidants significantly affected root length, root fresh weight $(\mathrm{mg})$, root dry weight ( $\mathrm{gm}$ ) and seedling vigour index. The tallest roots $(10.62 \mathrm{~cm})$, the highest fresh weight of root $(8.31 \mathrm{mg})$, dry weight of root $(2.93 \mathrm{gm})$ and seedling vigour index (1703.3) are obtained from the control treatment and without antioxidant soaking. At the same time as, the lowly

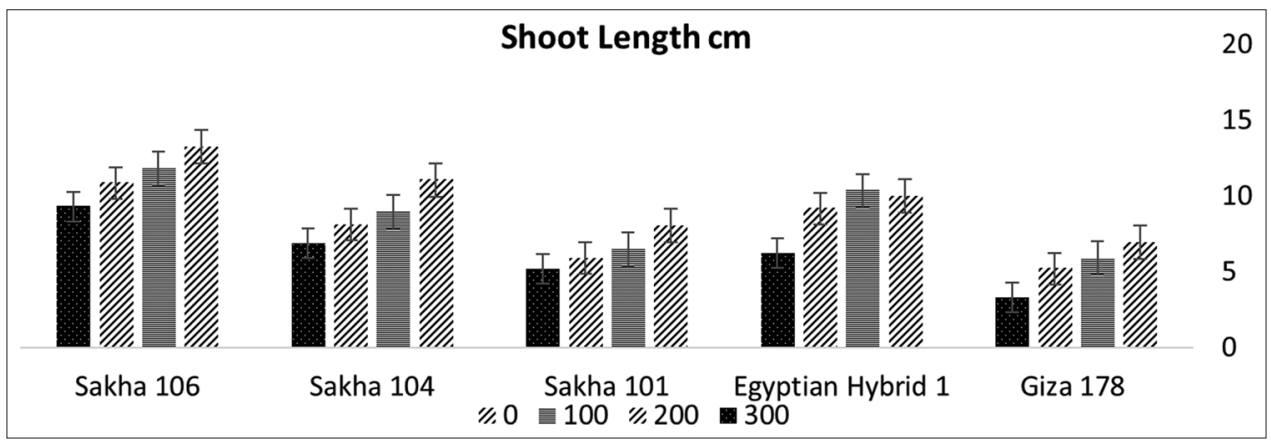

Figure 1: Means of length shoot as influenced by the interface of rice cultivars and NaCL concentrations.

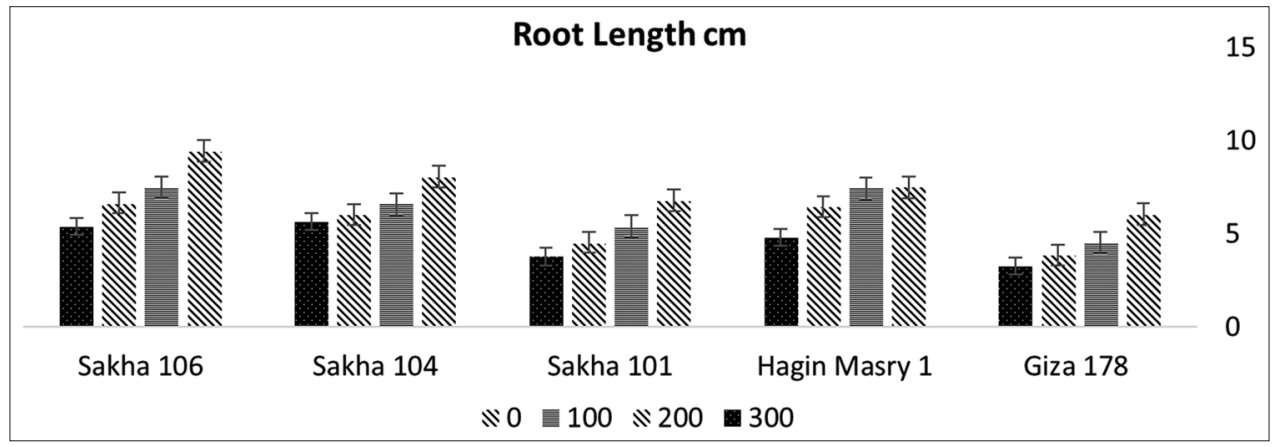

Figure 2: Average of the length of root as affect by the interaction between rice cultivars and NaCL concentrations.

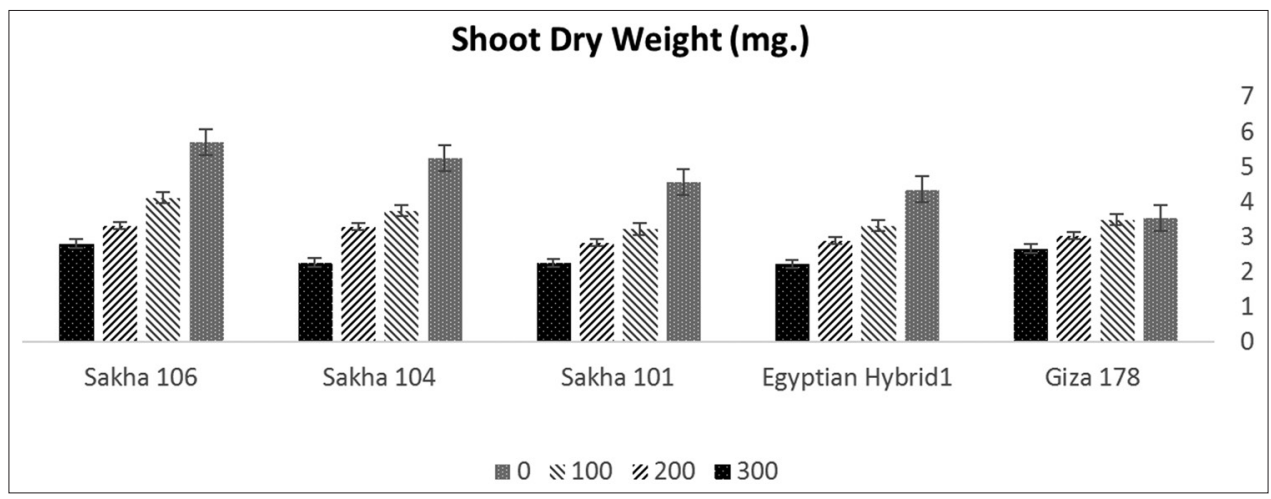

Figure 3: Average of the dry weight shoot $(\mathrm{mg})$ as affected by the interaction between rice cultivars and NaCL levels. 


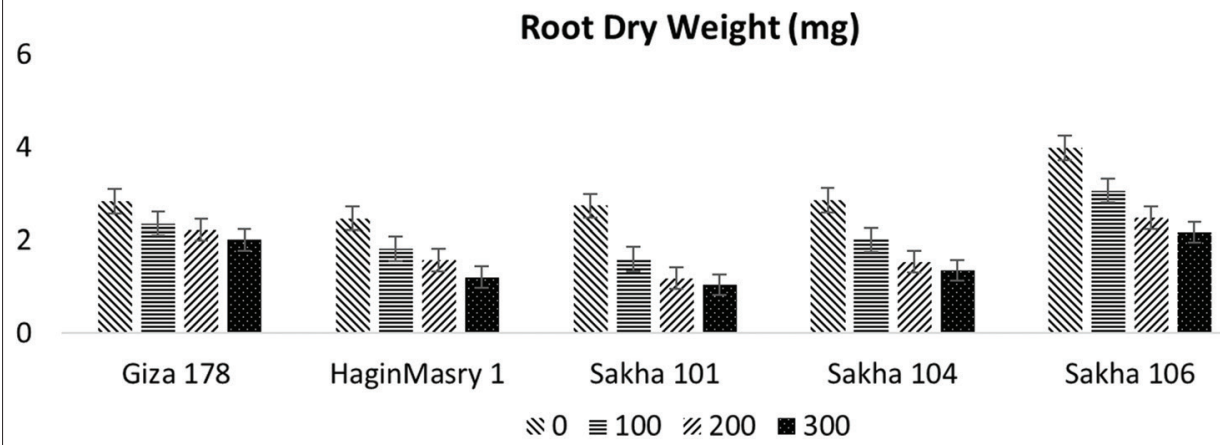

Figure 4: Means of the dry weight of root $(\mathrm{mg})$ as affect by the interface between rice cultivars and NaCL concentrations.

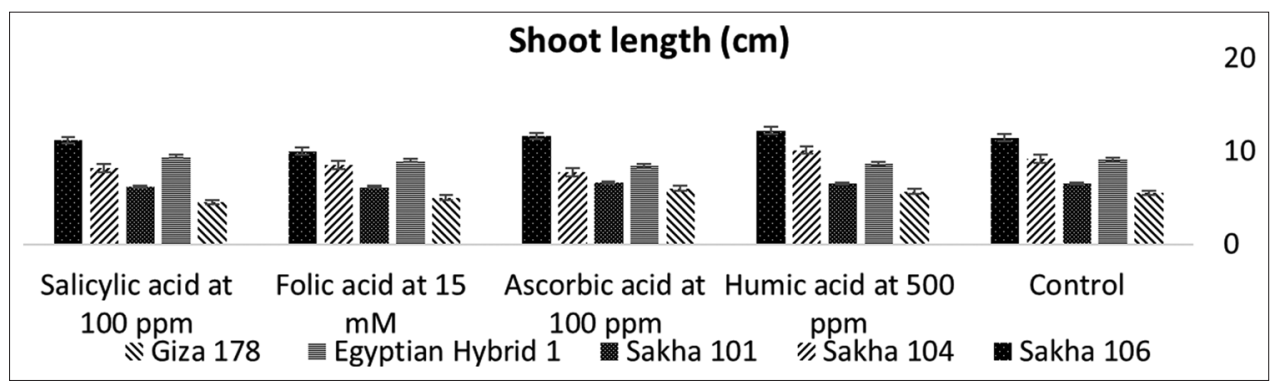

Figure 5: Average of the length shoot as affect by the relations between rice cultivars and antioxidants.

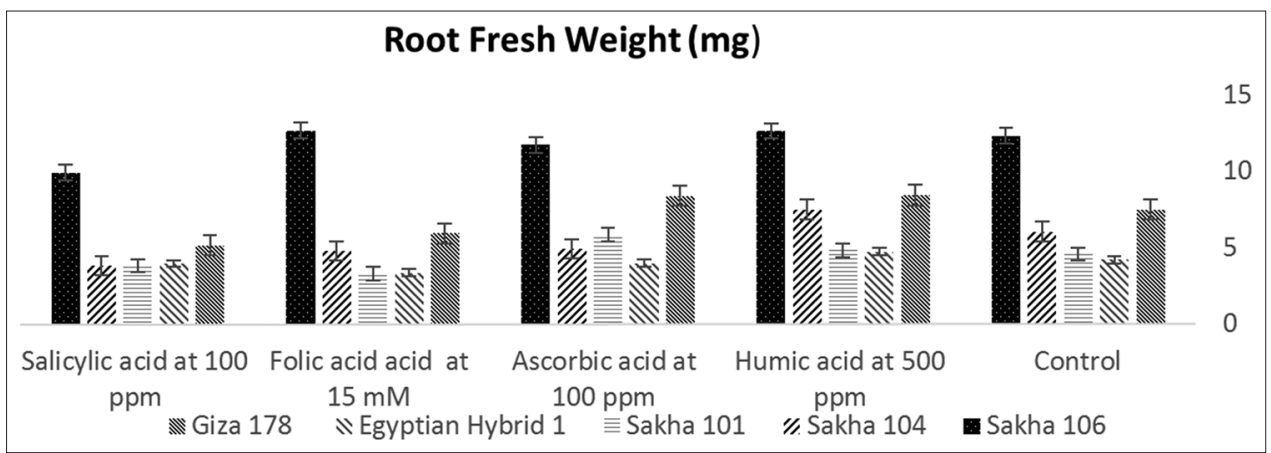

Figure 6: Average of the fresh weight root $(\mathrm{mg})$ as affect by the interaction between rice cultivars and antioxidants.

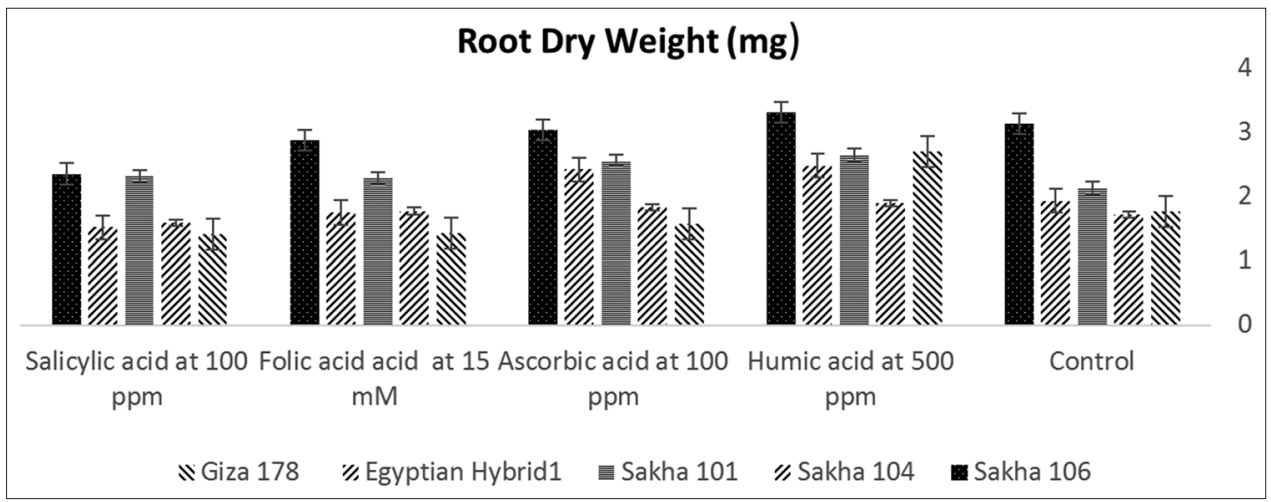

Figure 7: Average of the dry weight of root $(\mathrm{mg})$ as affect by the interaction between rice cultivars and antioxidants.

values of seedling root length, root fresh weight $(\mathrm{mg})$, root dry weight (gm) and seedling vigour index are shown in $300 \mathrm{mM}$ salinity of Nacl under Salicylic acid at $100 \mathrm{ppm}$. These results are in good accordance with those found by other studies $[6,7,8,11]$. 


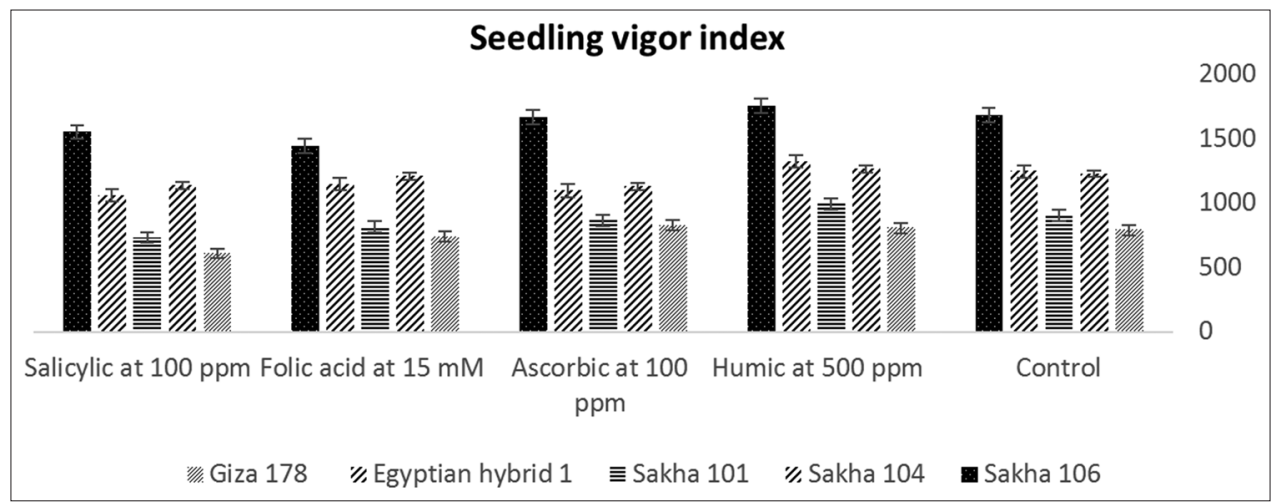

Figure 8: Average of the seedling vigor index as affect by the interaction between cultivars and antioxidants.

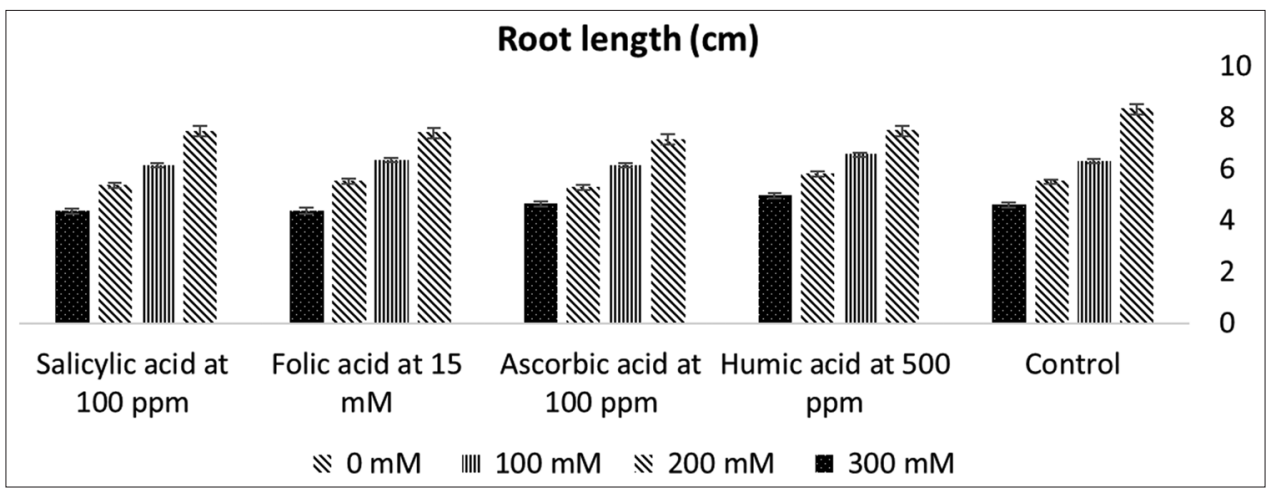

Figure 9: Averages the length of root $(\mathrm{cm})$ as affect by the interface effect between salinity levels and antioxidants.

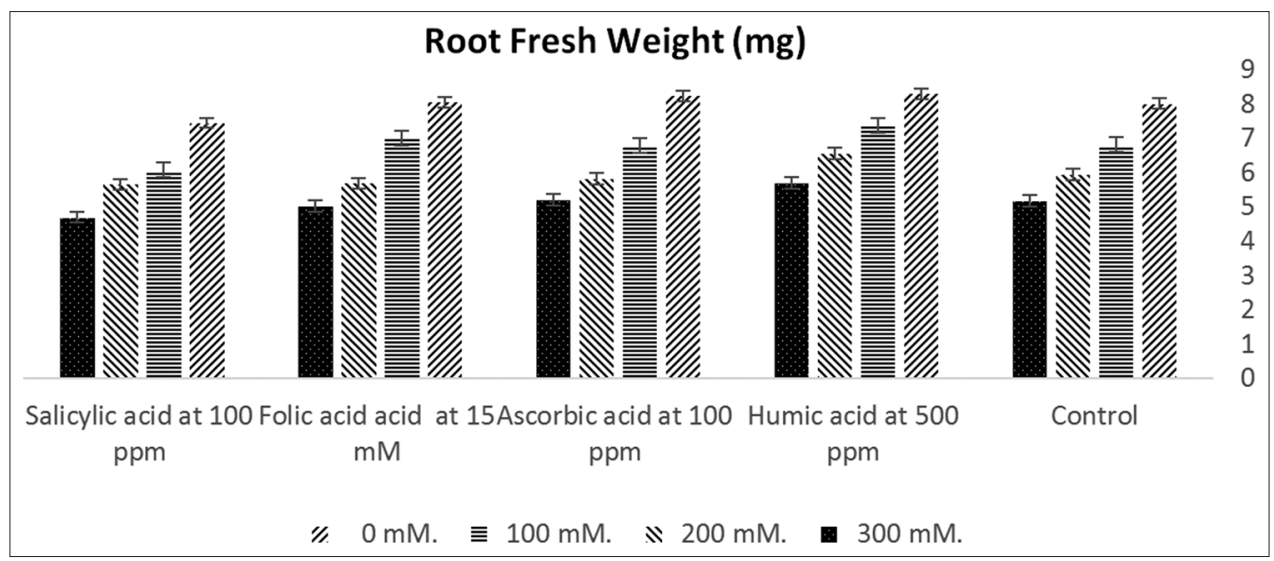

Figure 10: Means of fresh weight of root $(\mathrm{mg})$ as affect by the relations among of salinity levels and antioxidants.

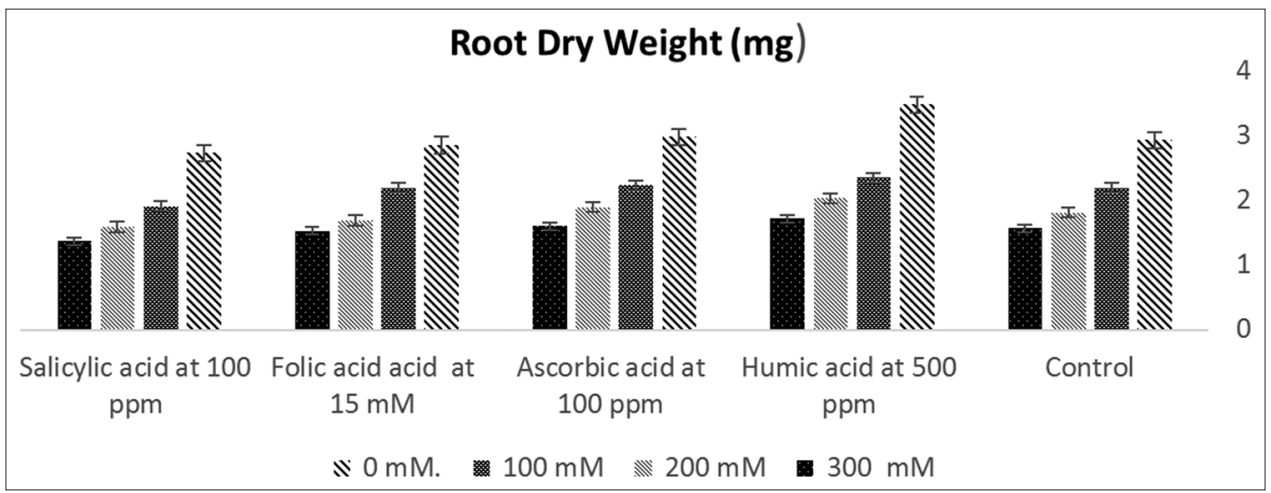

Figure 11: Average of the dry weight of root $(\mathrm{mg})$ as affected by the interaction among salinity levels and antioxidants. 


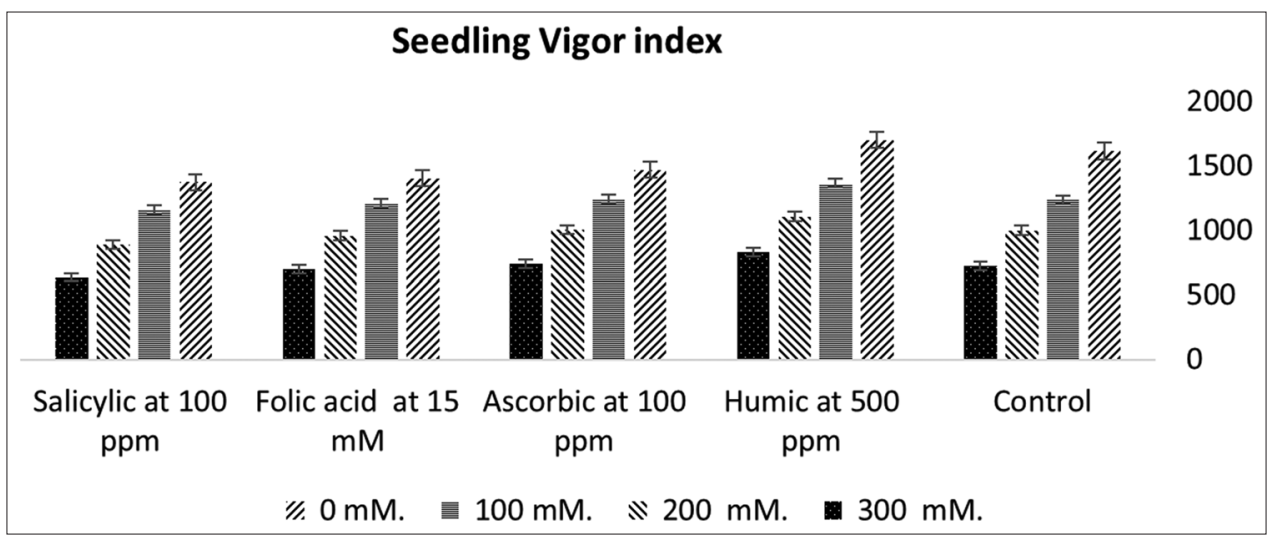

Figure 12: Percentages of seedling vigor index as affect by the interaction between salinity concentration and antioxidants.

\section{CONSOLATION}

In order to maximize seedling parameter of rice under salinity stress, it could be suggested that soaking Sakha 106 cultivar in Humic acid at $500 \mathrm{ppm}$. It can be used in breeding program to boost production.

\section{REFERENCES}

1. Zhu, JK. Over expression of a delta-pyrroline-5-carboxylate synthetase gene and analysis of tolerance to water and salt stress in transgenic rice. Tr. Plant Sci. 2001; 6: 66-72.

2. Munns, R, James RA, Lauchli A. Approaches to increasing the salt tolerance of wheat and other cereals. Journal of Experimental Botany. 2006 57(5), 1025-1043.

3. Chang, CS, Sung JM. 2004. Nutrient uptake and yield responses of peanuts and rice to lime and fused magnesium phosphate in an acid soil. Field Crops Res., 2004 89: 319-325.

4. Sahi, C, Singh A, Kumar K, Blumwald E, Grover A. Salt stress response in rice: Genetics, molecular biology and comparative genomics. Func. Integrative Genomics. 2006; 6: 263-284.

5. Zeng, Y, Zhang H, Li Z, Shen S Sun J. Evaluation of Genetic diversity of rice landraces (Oryza sativa L.) in Yunnan, China. Breeding Sci. 2007: 57: 91-99.

6. El-Manzlawy, AM, Ibrahim AEA. Influence of antioxidants pre-sowing on biochemical and seed vigor of some rice (Oryza sativa L.) varieties under salinity. J. Plant Production, Mansoura Univ.2011; 2 (7): 871 - 881.

7. Kochak-Zadeh, A, Seyyed-Hashem M, Eshraghi-Nejad M. The effect of salinity stress on germination and seedling growth of native and breeded varieties of wheat. Journal of Novel Applied Sciences. J Nov. Appl. Sci. 2013; 2 (12): 703-709.

8. Pushpalatha, GD, Subrahmanyam K, Sreenu T, Ram LV, Subbarao B Parmar A Giri N, Sarla Rai V. Effect of salt stress on seedling growth and antioxidant enzymesin two contrasting rice introgression lines. Indian J Plant Physiol.2013; 18(4):360-366.

9. Barus, WA, Rosmayati AR, Hanum C. Improvement of Salt Tolerance in Some Varieties of Rice by Ascorbic Acid Application. International journal of Scientific \& Technology Research. 2015, 4(5): 235-237.

10. Lutts, S, Kinet JM, Bouharmont J. 1995. Changes in plant response to $\mathrm{NaCl}$ during development of rice (Oryza sativus L.) ACKNOWLEDGMENTS varieties differing in salinity resistance. J. Exp. Bot.1995; 46:1843-1852.

11. Asch, F. Wopereis MCS. Responses of field-grown irrigated rice cultivars to varying levels of floodwater salinity in a semi-arid environment. Field Crop Res. 2001; 70: 127-137.

12. Soltani A, Gholipoor M Zeinali E. Seed reserve utilization and seedling growth of wheat as affected by drought and salinity. Environmental and Experimental Botany. 2006; 55 195-200.

13. Khanam, M., Al-yeasa M Rahman S Al-mahbub A Gomosta A. Effects of different factors on the growth efficiency of rice seedlings.
Bangladesh J. Bot.2007; 36(2): 171-176.

14. Abbas MK, Ali AS, Hasan HH, Ghal RH. Salt tolerance study of six cultivars of rice (Oryza sativa L.) during germination and early seedling growth. Journal of Agricultural Science. 2013;5(1):250.

15. Ghosh, B, Ali Md N Saikat G. Response of Rice under Salinity Stress: A Review Update. J Res Rice 4: 167.

16. ISTA Rules 2017.International seed testing association. ISTA Germination Sec. Chapter 19: pp. 19 - 41

17. Abdul-Baki, AA. Anderson JD. Viability and leaching of sugars from germinating barley. Crop Sci.1970; 10: 31-34.

18. Islam, MM, Karim M A. Evaluation of Rice Oryza sativa L. genotypes at germination and early seedling stage for their tolerance to salinity. The Agric.2010;8 (2): 57 - 65.

19. Gomez, KA. Gomez AA. Statistical Procedures in Agricultural, Research, John Wiley and Sons, New York, 1991.

20. Snedecor GW, Cochran WG. Statistical Methods. 7ThEd. Iowa State University Press, lowa, USA, 1980; ISBN-10: 0-81381560-6, Pp: 507

21. Danai, S, Kumar V Shriram V. Differential response of two scented Indica rice (Oryza sativa) cultivars under salt stress. Journal of stress Physiology \& Biochemistry. 2011 (4): 387-397.

22. Habib, N; Muhammad, A Ahmad MS A. Enhancement in seed germ inability of Rice (Oryza sativa L.) by pre-sowing seed treatment with Nitric Oxide (NO) under salt stress. Pak. J. Bot.2010; 42(6):4071-4078.

23. Saqib, M, Akhtar J Qureshi RH. Sodicity intensifies the effect of salinity on grain yield and yield components of wheat. J Plant Nutr. 2008; 31:689-701.

24. Rao, PS., Mishra B, Gupta SR Rathore A. Reproductive stage tolerance to salinity and alkalinity stresses in rice genotypes. Plant Breeding.2008; 127:256-261.

25. Fageria, NK, Stone LF Santos ABD. Breeding for salinity tolerance. In: R Fritsche-Neto, A Borém (Eds) Plant Breeding for Abiotic Stress Tolerance, Springer-Verlag Berlin, Germany,2012; pp: 103-122.

26. Moud, A M, Maghsoudi K.Salt stress effects on respiration and growth of germinated seeds of different wheat (Triticum aestivum L.) cultivars. World J. Agric. Sci.2008; 4(3): 351-358.

27. Maryam, A, Faghami ERole of salicylic acid and ascorbic acid in the alleviation of salinity stress in wheat (Triticum aestivum L.). Journal of Biodiversity and Environmental Sciences.2015; 6 (2): 107-113, 2015

28. Mehdi D, Poodineh Z, Fakheri B A. (Effects of Humic and Folic acid on Quantity and Quality Related Traits of Button Mushroom (Agaricus bisporus). Biological Forum - An International Journal. 2015; 7(1): 823- 828.

29. Mahdieh. E, Mrir Effect of Humic acid on seed germination and seedling growth of Borago officinalis and Cichorium intybus. Ecopersia 2016;4(1), 1239-1240.

30. Amin,AA Abd El-Kader A, Magda Shalaby AF, Fatma Gharib AE, ElSherbeny MR. Jaime A, Teixeira dS. Physiological effects of salicylic acid and thiourea on growth and productivity of maize plants in sandy soil. 2013 pp 1141-1155.

31. Yousof, FI, Mersal IFEL-Emam AAM. Effect of soaking rice(Oryza sativa L.) Seed in some anitioxidants solutions on germination and seedling vigor under different salinity levels. J. of Plant Production. 2010; 1 (2): $279-290$ 